2004

\title{
Radical Responses to the Great Depression
}

Hand, Franki; Daub, Peggy; Herrada, Julie

https://hdl.handle.net/2027.42/120273

https://creativecommons.org/licenses/by/4.0/

Downloaded from Deep Blue, University of Michigan's institutional repository 


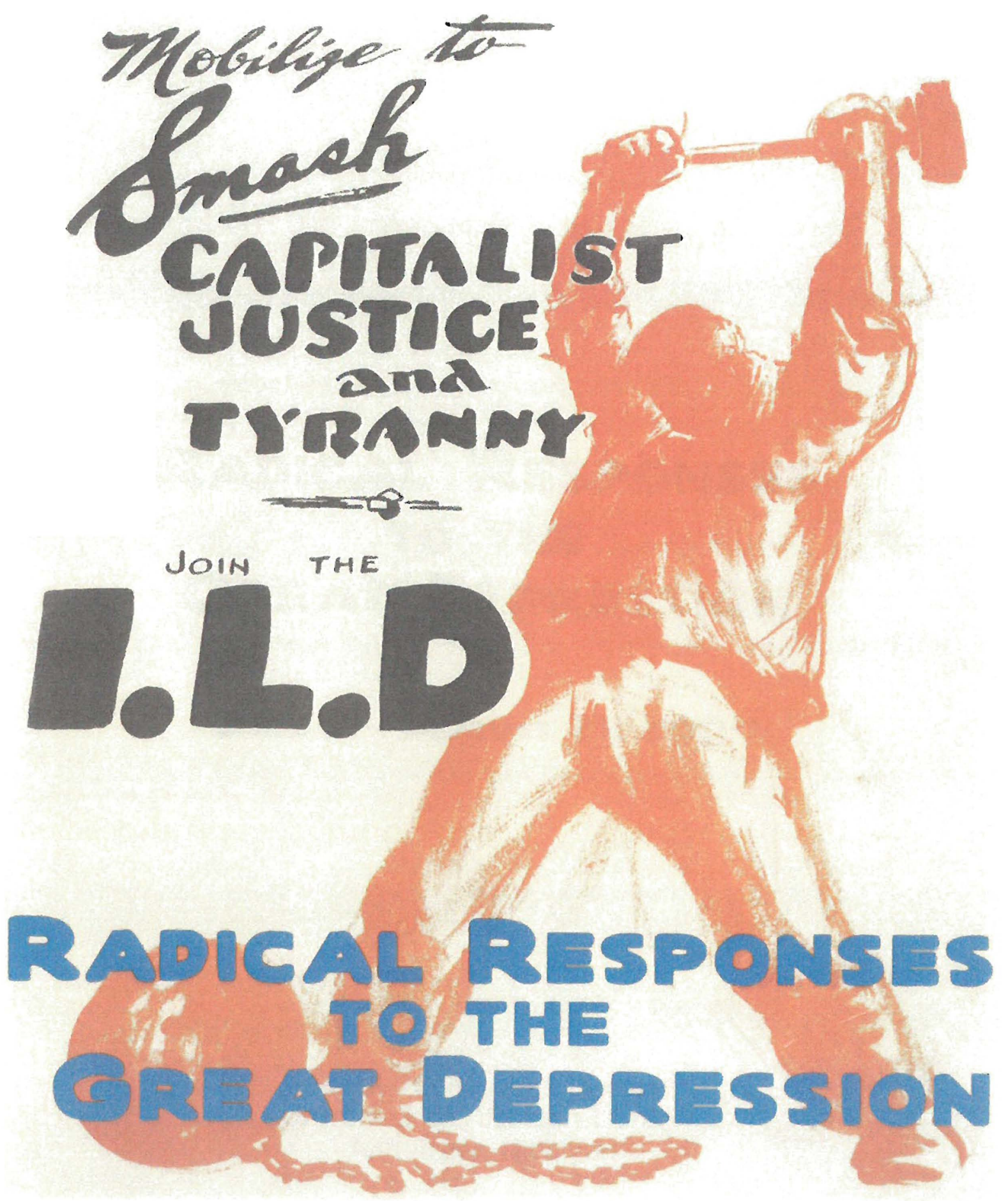




\section{RAdical Responses TO THE GREAT DEPRESSION June 7 - August 21, 2004}

Special Collections Library University of Michigan Library Ann Arbor, Michigan 


\section{Introduction}

Welcome to the exbibit "Radical Responses to the Great Depression". This exbibit was originally created in 1985 by Edward Weber, Curator Emeritus of the Labadie Collection. The current version has been revived and expanded by current Curator of the Labadie Collection, Julie Herrada.

Exhibit Hours:

10:00 A.M. - 5:00 P.M. Monday - Friday

10:00 A.M. - 12:00 P.M. Saturday

Copyright 2004 by the University of Michigan Library University of Michigan, Ann Arbor.

University of Michigan Board of Regents:

David A. Brandon Rebecca McGowan

Laurence B. Deitch Andrea Fischer Newman

Daniel D. Horning S. Martin Taylor

Olivia P. Maynard Katherine E. White Mary Sue Coleman (ex officio)

Cover design by Franki Hand
The Labadie Collection is one of the world's strongest assemblages of materials documenting radical social movements, and this exbibit demonstrates both the depth and the breadth of its holdings. For this one slice of American bistory, the Labadie Collection materials on display range from manuscripts and books to posters, pamphlets, and newspapers, along with artifacts such as buttons and stamps. Of special note are the items from arcbival collections added since this exhibit was first shown, including the papers of Abe Bhuestein, Ammon Hennacy, and J. Louis Engdabl. Some of the radical novels on display are from the general book collections of the Special. Collections Library, and one item is borrowed from the sheet music collections of the Music Library.

The curator of this exhibit, Julie Herrada, was ably assisted by staff from the Special Collections Library (notably Franki Hand, Corinne Forstot, and Joanna Axelrod) and from the Conservation Department of the Library's Preservation Unit (Thomas Hogarth and Leyla Lau Lamb).

Peggy Daub, Head

Special Collections Library 
The Great Depression conjures up one of the profound American twentiethcentury experiences. Unlike earlier depressions and periods of hard times, this economic paralysis was of a magnitude and duration that approached trauma; and although amelioration was evident after federal relief measures were taken, the long-awaited recovery never took place. The Great Depression lifted only as the economy stirred because of World War IX.

It was a time of breadlines, soup kitchens, and shanty settlements, punctuated by large-scale industrial strife as labor organization received a strong impetus. Yet for all the grimness of the picture, nostalgia recalls a sense of community such as America did not have before nor has felt since. Far-reaching social legislation was enacted in the hope of eliminating the worst poverty and averting future depressions. We cannot count the number of people who were crushed by the Depression, but the national psyche remained unscathed and even seemed breezily invigotated by the challenges. It was the last era of pre-A tomic Age security and the last wise-cracking time.

Almost all of the items exhibited here come from the Labadie Collection of social protest materials, with some augmentation from the main Special Collections Library, the Graduate Library, and the Music Library.

\section{Case 1: Unemployment, Hunger, and Deprivation}

\section{The Unemployed. New York: New York Chapter, League for Industrial Democracy, 1930-32.}

Much more handsome than its title would suggest, The Unemployed was published by the League for Industrial Democracy, affiliated with the Socialist Party. Its five issues (1930-32) mirrored the concern of an ever-growing number of prominent writers, artists, and men of affairs: Norman Thomas, Heywood Broun, Reinhold Niebuhr, Carl Sandberg, Morris Ernst, Zona Gale, Morris Hillquit, Fanny Hurst, Alexander Woollcott, Stuart Chase, A. J. Muste, Frank Murphy, Reginald Marsh, Otto Soglow, John Sloan, Thomas Hart Benton, and Boardman Robinson.

The Labadie Collection's set of The Unemployed was a gift of the I.W.W. organizer, poet, and artist, Ralph Chaplin. 
The stock market crash of October 1929 signaled the end of the apparently prosperous Twenties, an age in which credit expansion had masked economic insecurity, rural stagnation, and widespread disparity of income. Cheerful prognostications about the temporary nature of the recession were belied by ever-rising unemployment figures. Although New Deal programs significantly diminished the number of workers without jobs, unemployment remained the specter of the decade and did not fade until America's involvement in World War II.

$\begin{array}{lll}\text { Year } & \begin{array}{l}\text { Unemployment } \\ \text { in labor force }\end{array} & \text { Percent } \\ 1929 & 1,550,000 & 3.2 \\ 1930 & 4,340,000 & 8.7 \\ 1931 & 8,020,000 & 15.9 \\ 1932 & 12,060,000 & 23.6 \\ 1933 & 12,830,000 & 24.9 \\ 1934 & 11,340,000 & 21.7 \\ 1935 & 10,610,000 & 20.1 \\ 1936 & 9,030,000 & 16.9 \\ 1937 & 7,700,000 & 14.3 \\ 1938 & 10,390,000 & 19.0 \\ 1939 & 9,480,000 & 17.2 \\ 1940 & 8,120,000 & 14.6 \\ 1941 & 5,560,000 & 9.9\end{array}$

(from Historical Statistics of the United States, U.S. Department of the Census)

Flyer. "All Out - Ford Hunger March". Dearborn, Michigan, June 5 , 1933. Co-sponsored by the Auto Workers Union and the Unemployment Councils.

The National Hunger March in Pictures. New York: National Committee Unemployment Councils of U.S., 1932.

New York Workers' Committee on Unemployment. New York: 1933.

Prominent in organizing the jobless and homeless were the Unemployed Councils that sprang up in the early 1930s. Their demands echoed the rhetoric and followed the counsel of the burgeoning Communist Party which controlled the National
Federation of Unemployed Councils. Belief in the efficacy of New Deal measure weakened support for these organizations, which were finally shelved by the Party in the Popular Front era of accommodation.

\section{Jay Gorney \& E. Y. Harburg. "Brother Can You Spare a Dime?” Autograph} score, 1932.

Jay Gorney \& E. Y. Harburg. "Brother Can You Spare a Dime?" New York: Harms, 1932.

Jay Gorney, one of the most active writers of popular songs during the 1920 s and 1930s, was a graduate of the University of Michigan in 1917 (A.B.) and in 1919 (LL.B.). After only one year in the practice of law, Gorney moved to New York City and established a very successful musical career. He wrote songs and directed and produced musical plays, tevues, and movies. Some of his bestknown songs were composed for Broadway shows, such as this famous depressionera song, "Brother, can you spare a dime", written for the musical revue, Americana, which opened on Broadway in 1932. The Jay Gorney Papers were donated to the University of Michigan in 1969

"Yip" (Edgar Yipsel) Harburg was born Inwin Hochberg in 1896 or 1898 on Manhattan's Lower East Side. When his small business failed during the Great Depression, he rapidly became successful as a lyricist. Over the years, he collaborated with many composers, including, Vernon Duke, Jerome Kern, and Jay Gorney, who wrote the music for "Brother, Can You Spare a Dime?" Harburg also wrote the lyrics for shows such as Finian's Rainbow and films such as The Wizard of $\mathrm{O}_{2}$ His long list of hit songs includes "April in Paris," "It's Only a Paper Moon," "Over the Rainbow," and "How are Things in Glocca Morra?" Harburg' Hollywood career came to a halt in the early 1950s when he was blacklisted. A Marxist and a democratic socialist, but never a Communist, he was staunch advocate of a variety of radical causes. He died on March 5, 1981 in Brentwood, California.

From "The Song", an interview with E.Y. (Yip) Harburg. In Hard Times An Oral History of the Great Depression, by Studs Terkel. N.Y. : Pantheon Books, 1970. 
"The prevailing greeting at that time, on every block you passed, by some poor guy coming up, was 'Can you spare a dime?' Or: 'Can you spare something for a cup of coffee?'...I thought that could be a beautiful title. If I could only work it out by telling people, through the song, it isn't just a man asking for a dime.

"This is the man who says: 'I built the railroads. I built the tower. I fought your wars. I was the kid with the drum. Why the hell should I be standing in a bread line now? What happened to all this wealth I created?' I think that's what made the song... It's more than just a bit of pathos. It doesn't reduce him to a beggar. It makes him a dignified human, asking questions -

"Everybody picked the song up.... When Roosevelt was a candidate for President, the Republicans got pretty worried about it. Some of the nctwork radio people were told to lay low on the song. In some cases, they tried to ban it from the air But it was too late. The song had already done its damage."

\section{Case 2: Radical Novels}

James T. Farrell. Tommy Gallagher's Crusade. New York: The Vanguatd Press, 1939.

The most grimly naturalistic of the radical novelists was James T. Farrell (1904 1979), who, born in Chicago and educated in parochial schools on the South Side, depicted with enormous and telling detail in the Studs Lonigan trilogy (1932-35) the sordid world of those not fortunate enough to escape the depressing mindless milieu of his own boyhood. This was followed by the Bernard Clate trilogy and a series devoted to Danny O'Neill - a large body of serious work by a writer of high social and political acumen. Tommy Gallagher's Crusade (1939), terse and caustic, is a distillation of Farrell's gifts of observation: the title character is an unemployed ignorant youth, pathetic in his stifled lusts, who tries to find compensation for his feelings of guilt and uselessness by enlisting in the anti-Semitic movement of Father Moylan (a thinly veiled portrait of Charles Coughlin).

Farrell has written, "If there is any hatred in my books, it is not directed against people but against conditions which brutalize human beings and produce spiritual and material poverty."
John Steinbeck. The Grapes of Wrath. New York: The Viking Press, 1939.

A series of successful novels dealing with the downtrodden in his native California (Tortilla Flat, 1935; In Dubious Battle, 1936; Of Mice and Men, 1937; and The Lon Valley, 1938) preceded John Steinbeck's Grapes of Wrath (1939), which made the Joad Family, displaced Oklahoma farmers in California, a household word and was hailed even on publication as the greatest modern American novel. Its frank language and honest depiction of sordid conditions brought Steinbeck censorship and much verbal abuse; but the novel won the Pulitzer Prize for 1940 and more than anything subsequently written gained for Steinbeck the Nobel Prize for Literature in 1962

Our copy is a first edition signed by the author, "For Brooks and Cy - in grateful memory of a hell of a lot of horse shit."

\section{John Steinbeck. The Grapes of Wrath. New York: The Limited Editions} Club, 1940.

So enthusiastic was the reception for Grapes of Wrath and so encomiastic the critics that one year after its publication the Limited Editions Club published a twovolume set with lithographs by Thomas Hart Benton.

\section{Richard Wright. Black Boy: A Record of Childhood and Youth. New York} Harper \& Brothers Publishers, 1945.

Richard Wright. Native Son. New York: Harper \& Brothers Publishers, 1940 .

Such black writers as Dunbar and Chesnutt had been largely forgotten, and the recent Harlem Renaissance had Twenties' affiliations that were unfashionable Wright, whose poverty-stricken boyhood in Mississippi is unsparingly detailed in his autobiography, Black. Boy (1944), found the proletarian spirit of the 1930 completely congenial, a natural outlet for writing about the black experience. Wright's first published book, Uncle Tom's Children_(1938), a collection of four novellas dealing with black oppression in the South, received glowing reviews (a notable exception being Zora Neale Hurston's in the Saturday Review of Literature) and 
Story magazine's prize for the best book-length manuscript submitted by anyone connected with the Federal Writer's Project. It was, however, Native Son which gained national and international acclaim. Writing in The Spectator, Rosamond Lehmann expressed the conclusions of most readers: "To me the scope and passionate sincerity of the book give it a grandeur, a moral importance at least as good as that of An American Tragedy".

As the decade came to its close, a major novel explaining territory unfamiliar to most American readers drew superlatives from critics in all camps: Richard Wright's Native Son (1940). Both Commonweal and the New Yorker compared it to Dreise and used the term "strong meat". "From the moment a giant rat steals into the Thomas family's one-room flat until Bigger in his death cell bids his attorney farewell, Native Son is a shocker".

John Dos Passos. The Big Money. New York: Harcourt, Brace and Co., 1936

John Dos Passos (1896-1970) was the ranking radical prose writer of the 1930s. Already famous for his Three Soldiers (1921), reflecting his disillusionment in World War I, and Manbattan Transfer (1925), an acidulous and powerful portrait of the prospering metropolis, Dos Passos sealed his reputation with the imposing trilogy U.S.A., in which American society is the central figure, with interesting devices of newspaper headlines and short character sketches of public figures to establish atmosphere. Some found the labor leader in The 42 ${ }^{\text {nd }}$ Parallel (1930) too idealized and wooden in a rather slow-moving story, but the breezy heroine of Nineteen Nineteen (1932) is his most appealing creation, in a swift and propelling narrative. The Big Money (1936), of which we show the first edition, portrayed characters resisting or embracing corruption by Coolidge prosperity on Wall Street and in Washington, Hollywood, and academia.
Case 3: Radical Appeals to the Literati and the Case of Tom Mooney

The Anvil. Moberly, Montana: The Anvil Press, March-April 1934. Left Front. Chicago: John Reed Club, September-Octobet 1933.

First organized in October 1929, the John Reed Clubs were a successful and highly interesting project by the Communist Party to appeal to intellectuals and to recruit aspiring writers. Left Front, the organ of the Chicago Club, was, with the New Masses and the Amvil, the first to publish the work of Richard Wright. Wright was deeply shocked in 1935 when the John Reed Clubs werc arbitrarily abolished to pave the way for the new Popular Front organization, the League of American Writers, and vividly conveyed his feelings about his whole involvement in the chapter he contributed to The God that Failed.

\section{I.J. Golden. Precedent: A Play About Justice. New York: Farrat \& \\ Rinehart, Inc., 1931.}

Block of Stamps. "Free Tom Mooney".

Envelope. "Free Mooney".

Ballot. "Mooney General Strike".

Tom Mooney (1892-1942), a member of the Socialist Party, was a labor agitator and anti-war activist living in San Francisco. In 1916, the Chamber of Commerce held a large Preparedness Day Parade to rally support for the European War. A bomb exploded at the parade and ten people were killed. Mooney and three other men, including Warren $\mathrm{K}$. Billings, were arrested and charged with the bombing, and Mooney was convicted of first degree murder and sentenced to death. Billings was convicted of second degree murder. After the trial evidence of perjury surfaced and the conservative Wickersham Commission concluded that the sole purpose of the trial was to convict Mooney and Billings. Thereafter, Mooney's death sentence was commuted to life. A huge international outpouting of public support followed in the next two decades. A European survey taken in 1935 showed that Mooney was one of four best known Americans, the others being Franklin D. Roosevelt, Charles Linbergh, and Henry Ford. Mooney was finally pardoned, but not until 1939, after 23 years in prison during which his health had suffered. He died a few years after. Billings was released with Mooney but not officially pardoned until 1961; he died in 1972. 
With Tom Mooney still serving his life sentence in a California prison, the case simmered on in the Thirties. I. J. Golden, a lawyer and amateur playwright, persuaded the Provincetown Theater to produce his drame á clef in April 1931. Btooks Atkinson of the New York Times wrote, "By sparing the heroics and confining himself chiefly to a temperate exposition of his case [Golden] has made Precedent the most engrossing political drama since the Sacco-Vanzetti play entitled Gods of the Lightening... Friends of Tom Mooney will rejoice to have his case told so crisply and vividly."

Clifford Odets. Three Plays. New York: Covici-Friede Publishers, 1935. Photograph (reproduction). John Garfield (1.) in Awake and Sing, 1935.

While Eugene O'Neill's naturalistic plays paved the way for the proletarian dramas of the 'Thirties, the ease of his dialogue and his intimate knowledge of the settings, not to mention his tragic vision, achieved a poignancy that his sermonizing successor could never reach. Nevertheless, the established playwright Elmer Rice won the Pulitzer Prize in 1929 for Sireet Scene, an artlessly moving drama that utilized a New York City tenement block, and went on to the more strident $W$ e the People (1933) and Judgment Day (1934), which were among the more effective agit-prop (agitation-propaganda) plays. It was, however, a new voice that best mirrored the radical aspirations in the theatre of the 1930s. Clifford Odets (1906-1963) was acclaimed by both the critics and the revolutionary vanguard alike for Waiting for Lefty (1935), based on the New York taxi cab strike of the preceding year, with the action laid in a union hall. This success prompted the staging in 1935 of his earlier Awake and Sing, his most personal and touching play, set in the Jewish ghetto. It was produced by The Group Theatre, founded in New York in 1931 , a company that produced contemporaxy plays dealing with social issues. With the Group Theatre also mounting Till the Day I Die, one of the first anti-Nazi dramas, Odets had three plays running simultaneously on Broadway and aroused more discussion than any American dramatist since O'Neill. Golden Boy (1937), about a young man who gives up his career as a violinist to ruin his hands in the boxing ring, was a popular success that has had a number of revivals.

\section{Case 4: Radical Novels II}

Marcet Haldeman-Julius and E. Haldman-Julius. Violence. New York: Simon and Schuster, 1929.

1929. "The action, set in the imaginary central southern state of Texlarkana" contrasts a murder committed by a white minister with that of a teenage mulatto boy; a lynch mob hangs a scapegoat. "Back of this bloody triangular dramatization is a portrayal of the life, at once decadent and barbaric, of the town's middle and younger generation, whose bodies and passions ripen early."

Gertrude Mathews Shelby and Samuel Gaillard Stoney. Po'Buckta. New York: Macmillan Co., 1930.

1930. To save her unproductive plantation, a pentiless woman marries a muscular "po' buckra" or poor white, who, unknown to her is really a "brass ankle" i.e. with strains of Negro and Indian blood. When the marriage fails and the plantation house becomes a rendezvous for bootleggers, she burns the mansion down in desperation.

Frederick Hazlitt Brennan. Pie in the Sky. New York: The Century Co., 1931.

1931. "The story of a fighting radical and his family, particularly the youngest son, who rebels against the narrow and conventional radicalism of his father and brothers and breaks away time and again."

\section{Myra Page. Moscow Yankee. New York: G.P. Putnam's Sons, 1935.}

1935. In this story of American mechanics and enginecrs in Soviet Russia, Andy, discharged from the Ford River Rouge plant, goes to Moscow and finds the life congenial and stimulating; when his American fiancée tefuses to come over, he marries a co-worker at his factory, the calm, organized Natasha.

Bettina Linn. Flea Circus. New York: Harrison Smith and Robert Haas, 1936. 
1936. Flea Circus pictures contemporary city life: a household of three Catholic priests and their Irish cook; a middle-class family torn by conflicts; and factory workers, their Communist associates, and a practical organizer for the Unemployed League.

\section{Emmett Gowen. Old Hell. New York: Modern Age Books, 1937.}

1937. A humorous treatment of a Tennessee mountain white, compared to Caldwell's God's Little Acre. The Author taught at Commonwealth College, closed in 1941 as subversive by the Arkansas attorney general. "Gowen is a backwoods Thurber. - Stanley Young, N.Y. Times

Chatles J. Bready. Red Alley. Cedat Rapids, Iowa: The Torch Press, 1937

1937. Dialogues on timely topics by the Whitmanite anarchist and poet

Charles Eskine Scott Wood. Earthly Discourse. New York: The Vanguatd Press, 1938.

1938. Satire and melodrama wrestle in this story about strike-breaking in a corporation-owned town.

Frank Dudley. King Cobra. New Yotk: Cartick \& Evans, Inc., 1940.

1940. The Red Riders are a secret "patriotic" organization that, becoming famous and wealthy, turns into feuding factions. The author, Ward Greene, was so fearful of retaliations by the Ku Klux Klan that he adopted a pseudonym for this novel

\section{Michael Gold. The Hollow Men. New York: International Pub., 1941.}

1941. Mike Gold was the Communist Party's most talented writer, who attempted to be an American Gorky; Jews Without Money, a novel based on his upbringing on the Lower East Side, is a minor classic. In the essays of The Hollow Men, Gold, the puritan and partisan, praises social realism and the young writers affiliated with the Communist Party, attacks the intellectuals who have deserted it because of their support for the "imperialist war" against Hitler, and once again takes up the cudgels against decadence personified by Thornton Wilder.
Robert Gessner. Here is My Home. New York: Alliance Book Corporation, 1941.

1941. Disenchanted with New York City, a Jewish immigrant makes his caree with a dry-goods store in the Midwest; he and his broad-minded wife are natural targets for the Ku Klux Klan.

Caroline Slade. Sterile Sun. New York: The Vanguard Press, 1936.

1936. Because Caroline Slade's first novel dealt frankly with prostitution, its nervous publisher put this amusing disclaimer on the dust jacket:

Sterile Sun is issued in a special edition, the sale of which is

limited to physicians, psychiatrists, sociologists, social workers,

educators and other persons having a professional interest in

the problems of adolescence.

Marc Blitzstein. The Cradle Will Rock: A Play in Music. New York: Random House, 1938.

Marc Blitzstein (1905-1964) was compared to both Weill and Brecht, the masters of world proletarian opera, with at least this justification: his facility enabled him to write text and music for a series of works whose commitment to a radical overturn of American Society was never in question. Received with enormous enthusiasm in 1937, after drama-laden attempts at suppression. The Cradle Will Rock takes place in Steeltown, U.S.A., where Larry, the union organizer, confronts Mr. Mister, the unscrupulous steel magnate who welds newspapers, citizens committees, unctuous clergy, and obsequious professors into a front to resist the labor drive in his plant. Brooks Atkinson wrote, "Written with extraordinary versatility and played with enormous gusto, it is the best thing militant labor has put in a theatre yet... What Waiting for Leffy was to the dramatic stage, The Cradle Will Rock is to the stage of the labor battle song... a triumph of the politically insurgent theater."

Breezy humor, more than the often heavy satire, has resulted in a number of revivals of The Cradle Will Rock, notably the 1947 direction of Leonard Bernstein and the memorial production of 1964. Blitzstein's love for the proletariat led to 
his being in the small number (with Leclair and Magtard) of composers who were murdered. The event was noted only tersely in 1964, but Truman Capote supplied the details in Music for Chameleons.

Case 5: Organizations: Labor Unions, the Communist Party, and the Socialist Party

A New Blow at Labor, No Union can Feel Secure while the Apex Verdict Stands; Congress Must Amend the Sherman Act. Washington: Congress of Industrial Organizations, 1940.

Don't Be Fooled! It's Your Wages and Yout Unions They'te After.

Washington: Congress of Industiral Organizations, 1939.

With collective bargaining guaranteed by the Wagner Act of 1935 , American labor made the greatest strides in its history by industry-wide organization of the great manufacturing plants. Michigan, the seat of the automobile industry, witnessed some of the most dramatic conflicts (see Wall Case III), and never was public opinion more aroused than by the sit-down strikes, which were seen on one hand as the flagrant abuse of private property tights and on the other as the ultimate weapon of syndicalist-minded workers.

Leon Trotsky. I Stake My Life! New York: Pioneer Publishers, 1937.

Photograph (reproduction). Leon Trotsky.

Advertising Card for lecture by Jay Lovestone, 1934.

Button. "Socialist Party".

While established groups like the Socialist Labor Party, the Socialist Party of the United States, and the Communist Party gained new life and adherents during the Depression years, factional disputes resulted in a remarkable proliferation of radical political organizations, most of them pledging allegiance to the ideas of Leon Trotsky, whose Fourth International was founded in 1938

Constitution of the New York State Socialist Party. Mimeograph. 1936. Membership Application. Socialist Party, New York City.

Block of Stamps. "Thomas for President".

Button. "Vote Norman Thomas Socialist".
Norman Thomas (1884-1968), an ordained minister and pacifist, was one of the founders, with Scott Nearing, A.J. Muste, and Oswald Gartison Villard of the Fellowship of Reconciliation. A few years later, in 1917, he helped found the National Civil Liberties Bureau, later to be named the American Civil Liberties Union. After Eugene Debs died, Norman became the Socialist Party's presidential candidate in 1928, 1932, and 1936. He wrote several books and was a frequent contributor to The Unemployed (see Case 1).

\section{Case 6: The Case of the Scottsboro Boys}

Flyer. Save the Scottsboto Boys: Smash All Racism. West Side Workers Forum, 1933.

The cause célebre of the 1930s, equal to the Sacco-Vanzetti case of the previous decade and the Tom Mooney frame-up of the 1910s, was the Scottsboro Case In March 1931, nine male black teenagers were hauled off a freight train in northern Alabama after a fight with a gang of white youths. Very shortly, however, they faced charges of rape on the word of two white prostitutes, who had been taken off the same train. Despite the fact that medical examinations showed no evidence, the "Scottsboro Boys" were convicted and eight of them sentenced to death in Roman carnival atmosphere, so prejudicial that the U.S. Supreme Court ordered a new trial. The trials, the rival defense committees with their publicity campaigns, the sufferings of the victims, and the illogical verdicts form a saga of civil rights in the 1930s. As they became less useful to partisan causes and to further fundraising, the Scottsboro Boys sank into obscurity. It was not until 1950, nineteen years after the arrests, that the last victim of the false rape charges left the Alabama prison system.

B.D. Amis. They Shall Not Die! : The Stoxy of Scottsboto in Pictures. New York: Workers' Library Publishers, 1932.

Alabama Circuit Court Judge James E. Horton, after presiding over the 1933 Decatur trial of Haywood Patterson, threw out the guilty verdict as incompatible with the evidence, and a new trial was granted. This courageous act brought an end to his political career and made him a social pariah but was highly influential in drawing attention to the gaps and contradictions in the prosecution's evidence. 


\section{John Wexley. They Shall Not Die. New York: Alfred A. Knopf, 1934.}

Already well known for his Death House play, The Last Mile (1931), John Wexley (1907-1985) turned his dramatic gifts to the Scottsboro Case. On February 21 1934, the Theater Guild presented They Shall Not Die at the Royale Theater, New York City, in a production by Theresa Helburn and Lee Simonson, with the latter's settings. The cast included Ruth Gordon, Helen Westley, Dean Jagger, Claude Rains, and Ben Smith. Carefully following in detail the events of the arrests and trials, the play was a documentary of great force and eloquence. Brooks Atkinson wrote, "For once good works match the crusader's intentions." After fifty year one would take exception only to the hortatory agit-prop (agitative political propaganda) of the very ending.

\section{Paul Peters. 8 Who Lie in the Death House. [S.I.: s.n., 1933?].}

Flyer. Great United Front Mooney-Scottsboto Mass Meeting Bronx Coliseum. [New York], 1933.

The grim experiences of the Scottsboro Boys in Alabama prisons were discreetly veiled as long as appeals were lodged in the courts. After his dramatic escape in 1948, Haywood Patterson wrote an exposé in collaboration with Earl Conrad. Ironically, while peddling this book, Patterson got into a barroom knife fight in Detroit and received a 15-20 year sentence at Michigan State Prison, where he died from cancer in 1952

Autograph Letter. J. Louis Engdahl to Pauline Engdahl, May 7, 1932.

Photograph (reproduction). J. Louis Engdahl and Ada Wright in Prague, September 1932.

A member of the Socialist Party and writer for several newspapers such as the Daily World and the Chicago Daily Socialist, J. Louis Engdahl (1884-1932) was one of the most distinguished editors in the history of American socialism. Engdahl became chairman of the International Labor Defense, and editor of its popular magazine, Labor Defender. The IID organized mass protests in support of "class war prisoners," including Tom Mooney and the "Scottsboro Boys." In 1932, Engdahl and Ada Wright--mother of two of the Scottsboro defendants, Andy and Roy-embarked on an extensive tour of Europe and the Soviet Union to gather international support for these frame-up victims. Engdahl and Wright were prohibited from entering several countries, including Belgium, Czechoslovakia, England, and Ireland, and were jailed in several others. Despite such setbacks, however, the tour was a success: In six months Engdahl and Wright addressed some two hundred mass meetings in sixteen cities. All over Europe Tom Mooney and the Scottsboro Boys were now recognized as working-class heroes, and millions of European trade-unionists and political organizations joined in the demand for their freedom. In Moscow, while attending the World Congxess of International Red Aid, Engdahl contracted pneumonia and died there. 5,000 wotkers attended his funeral. Shown here is a letter from Engdahl to his wife while on this tour. The J. Louis Engdahl Papers were acquired in 2001.

Case 7: Voices from the Right

The Thirties witnessed the rise of radical right demagogues, who for the first time achieved a national audience. As radio became a common pastime demagogues found it an efficacious way of convincing multitudes of the miracles ahead if their messages were only heeded.

An Open Letter! To the AFL and All Other Labor Union: To All Labor and Fraternal Organizations, Negro and White: To the Socialist Party. Signed Communist Party, District 24. New Orleans, Louisiana: Trades Council Allied Printing, n.d.

Photograph (reproduction). Huey Long.

Of the radical right figures in the 1930s, Huey P. Long (1893-1935) was the only person to wield political power, becoming governor of Louisiana in 1928 and U.S. senator in 1932. During 1934 and 1935 the servile Louisiana legislature enacted without debate a series of laws that abolished local government and gave the Long machine control of the appointment of every policeman, fireman, and teacher in the state, while the "Kingfish's" control of the militia, the judiciary, the election officials, and the tax assessors put all citizens at his mercy with no possibility of redress. The end came only with his assassination in September 1935. The flamboyant oratory and populist vocabulary of this vulgar demagogue, his widely heralded "Share-Our-Wealth Society" and especially his slogan, "Every Man a King", made Long the idol of millions; his first name became popular for male infants. Robert Penn Warren's novel All the King's Men (Pulitzer Prize, 1947) was based largely on Long's career, and with its very successful filming Long is perhaps 
more familiar to contemporary audiences than any other political figure of the Thirties except Franklin Roosevelt. The flyer shown complains of actions by Long and the Louisiana legislature.

Rev. Charles E. Coughlin. Lecture: The Call to Arms! Detroit, Michigan: Condon Printing Co., 1933.

Rev. Charles E. Coughlin. A Series of Lectures on Social Justice. Royal Oak, Michigan: The Radio League of the Little Flower, 1935.

Rev. Charles E. Coughlin. "Persecution-Jewish and Christian" and "Let Us Consider the Record". Royal Oak, Michigan: Condon Printing Co., 1938.

Photograph (reproduction). Rev. Charles E. Coughlin.

The Reverend Chatles E. Coughlin (1891-1979), pastor of the Shrine of the Little Flower, Royal Oak, Michigan, passed in early Depression days from weekly radio sermons (in a tich dulcet voice) to radio talks on money and economics attacking "international bankers". In 1932, he supported the candidacy of Franklin Roosevelt, proclaiming "Roosevelt or Ruin", but very shortly turned against the New Deal Increasing anti-Semitic comments, a large tolerance for Hitler's Germany, intemperate attacks on American political leaders, and support for the Union Party's Lemke ticket in 1936 swelled the ranks of his followers but drew reprimand from the Vatican. In 1937, Coughlin was attacked in the Michigan Catholic by the new Archbishop of Detroit, later Edward Cardinal Mooney, but was not completely silenced until federal threats of a sedition trial in 1942

Francis E. Townsend. 33 Questions \& Answers. Chicago: Townsend National Weekly, Inc., 1938

The mild-mannered California doctor Francis E. Townsend (1867-1960) proposed a national scheme by which every person over 60 would be given a $\$ 200$ monthly pension, the spending of which would consume goods and create prosperity. Although exploited by the radical right and an ardent supporter of the Lemke ticket in 1936, Townsend drew attention to the plight of the indigent aged and undoubtedly helped the acceptance of old-age assistance.
George Morris. The Black Legion Rides. New York: Workers Library Publishers, Inc., 1936.

In 1935, the nation was shocked when a murder in Michigan, originally thought to be a gangland slaying, uncovered the existence of the Black Legion, a secret organization which was dedicated to hunting down Negroes, Jews, Catholics, and Communists. State, county, and city employees were required to swear they were not members throughout Michigan, which was the focus of the Black Legion's bombings, fires, floggings, and murders. Ironically, it was under the Michigan criminal syndicalism law, passed to punish Communists, that the investigatory grand jury was launched. More than fifty men in Michigan were sentenced to long prison terms for their vigilante actions. The Black Legion caused a brief national sensation; a leaden movie with this title starred Humphrey Bogart as a factory worker who succumbs to doctrines of hatred. The Ku Klux Klan condemned the Black Legion!

Free America! : Six Addresses on the Aims and Purposes of the German Amexican Bund. New York: A.V. Publishing Corporation, 1939.

T'he German-American Bund was Hitler's attempt to recruit Americans, so barefaced that it never achieved great numbers or influence. When America entered World War II, the members of the Bund attempted to destroy all of their connections, and the literature is consequently very tare.

\section{Case 8: The Spanish Civil Wat (1936-1939)}

The Story of Abraham Lincoln Battalion: Written in the Trenches of Spain. New York: Friends of the Abraham Lincoln Battalion, n.d.

Donation can for Disabled Abraham Lincoln Brigade veterans.

Announcement of film Fury Over Spain. Dettoit, Michigan: October 2, 1937.

To-Motrow. A New Series: Spanish Bulletin. London: December, 1936. Announcement (in Yiddish) of speech by Rudolph Rockex on Spain. New York: September 25, 1936.

Flyer. Heat the Truth About Spain from the Spanish Delegation of the C.N.T. Detroit, Michigan: December 9, 1937. 
Flyer. To All the Workers in the World... The National Confederation of Labor, The Iberian Anarchist Federation, The International Liberation Committee Against Fascism in Spain. Detroit, Michigan: 1936.

Photograph. Abe and Selma Bluestein aboard the Antonia on their way to Spain, April 1, 1937.

Typed Letter. Abe Bluestein to Selma Bluestein, Madrid, November 6, 1937.

Far from the shores of America raged the struggle against Franco's brutal fascist regime. No other international issue had managed so fervently to capture the hearts and souls of American intellectuals and radicals. Their experiences during the Depression moved them to a greater urgency in fighting against injustice and repression. The tesponse of the Spanish working class against Franco advanced their ideals of building an egalitarian society by collectivizing land, industry, and public utilities, and closing down the pro-fascist Catholic churches. The U.S. Government did not enter this war, but nearly 3,000 Americans volunteered with the International Brigades, leaving behind home and family, and establishing the first racially integrated military unit in U.S. history. As many as one million people are believed to have died duxing the War, and many others were forced into exjle.

Abe and Selma Bluestein (pictured), New York anarchists, traveled to Spain in 1937, arriving in Barcelona shortly before the now famous "May Days," when anarchists and Marxists were confronted by Communist and government forces in a bloody battle. Abe reported on the War for Freie Arbeiter Stimme, the longrunning Yiddish anarchist weekly in New York and Selma was involved with the artist's community. Abe also served as information officer for the CNT (Confederación Nacional del Trabajo/National Confederation of Labor), gave radio broadcasts for the anarchist fighters in Barcelona and other parts of Catalonia, and sent weekly news bulletins to U.S. and British publications. Shown here is one of the letters Abe wrote to Selma after she returned home a few months before him.

Franco's regime continued for several decades after the official ending of the Spanish Civil W/ar, until his death in 1975.

The Abe Bluestein Papers were a gift to the Labadie Collection in 1997.

\section{Case 9: The Case of Tom Mooney}

Large poster. "Labor Martyr Immortalized in poem". Stone Face, by Lola Ridge, with photo of Tom Mooney in prison grays, 1932.

Wall Case I: The WPA Federal Theatre Project

Photograph (reproduction). Hallie Flanagan.

Autograph Letter. Hallie Flanagan to Agnes Inglis, February 24, 1946.

Photograph (reproduction). Virgil Geddes, Hallie Flanagan, and Harry

Hopkins in the lobby of the Experimental Theatre.

The Living Newspaper, Vol. 2, No.1. February 23, 1937.

Typed Letter. Hallie Flanagan to Agnes Inglis, October 1, 1942.

In one of its most controversial moves, the Works Progress Administration decided to provide jobs for unemployed writers, actors, artists, and musicians. The social content of the books, plays, and murals produced by federal projects was anathema to conservatives, but the level of achievement appears very high as the decades have passed. At its peak the Federal Theatre employed 10,000 people, over half of them in New York City. Twelve million people attended its performances there. Under the Project, many theatre companies sprang up throughout the country as well. Many of the Federal Writers'state and local guides have been reprinted in recent years

Hallie Flanagan, who had gained attention with her work at the Vassar Experimental Theater, headed the Federal Theater Project. The Special Collections Library has some of her correspondence with Agnes Inglis, the first curator of the Labadie Collection, and with Professor Kenneth Rowe of the English Department at the University of Michigan, who promoted the plays of students in his courses here and worked for ties with the Federal Theater. Flanagan returned to Vassar in 1939, became Dean and Director of Theatre at Smith College in 1945, and retired in 1952.

Hallie Flanagan appeared less spirited when she was admonished by the Dies Committee for such productions as One Third of a Nation by seventeenth-century playwright Christopher Marlowe. It was at this hearing that Congressman Joe Starnes of Alabama asked if Marlowe was a Communist and wanted to investigate him. See Thirty Years of Treason: Excerpts from Hearings before the House Committee on Un-American Activities, edited by Eric Bentley (Viking, 1971). 
Poster (in Romanian). "Concert International" sponsored by the Grupul Roman I. W. W. in Detroit. Detroit, 1935.

Although its greatest days were past and its anti-Communism made it abhorrent to fellow travelers, the Industrial Workers of the World worked on through the 1930 s, overshadowed by the big labor organizing drives. The I.W.W. was notably successful in recruiting foreign-born labor, as this poster for a Detroit Romanian group gives evidence.

Poster. "Mobilize to Smash Capitalist Injustice and Tyranny: Join the I. L. D." New York: International Labor Defense, [1930?]

Of the many Communist Fronts during the Thirties, the International Labor Defense (1925-1946) was one of the most active and flamboyant, devoted to victims of class warfare. It quickly displaced the NAACP as counsel for the Scottsboro Boys (see Case 6) and dramatically publicized the affair with meetings, parades, and fund-raisers across the country. However, the ILD jeopardized it control of the Scottsboro Case by a clumsy attempt to bribe Victoria Price, the alleged victim who had persisted in her rape charges, and was finally replaced by a united front of socialists, clergymen, and civil libertarians, the Scottsboro Defens Committee. Less active during and aftet the Popular Front, the ILD was finally dissolved after World War II.

\section{Wall Case III: Violence in Labor Strikes}

Flint Journal, February 1,1937. Extra. "Riots at Chevrolet as Strikers Attack."

Flint Journal, February 2, 1937. Extra. "Peace is Restored as Troops Control Chevrolet Fisher 2".

These editions of the Flint Journal (1937), undoubtedly hawked by newsboys shouting "Extra!" display dramatic events of the Sitdown Strike.

\section{Homemade Steel "Knuckles".}

These steel "knuckles" are said to have been used at the "Little Stcel Strike," summer 1937, at the Republic Steel plant in Cleveland, Ohio.

\section{Wall Case IV:}

The Catholic Worker. Vol. 6, no. 1, May 1936.

Typed Letter. Dorothy Day to Ammon Hennacy, 1952.

The Catholic Workers are pacifist anarchists who base their beliefs and actions on the teachings of Jesus within the framework of the Roman Catholic Church. Dorothy Day (1897-1980) founded and edited the small but influential Catbolic Worker in 1933; and very suspiciously was the first issue received by other radicals in Union Square on May Day of that year. Stark woodcuts by Ade Bethune have adorned the Catholic Worker for six decades. In the same tradition are the contributions of Fritz Eichenberg (1901-1990) from the post-war period.

Social Justice. October 3, 1938.

Photograph (reproduction). Rev. Charles E. Coughlin.

Social Justice (Royal Oak, Michigan, 1936-42) was the journal of Father Coughlin (see Case 7) and what Tommy Gallagher peddled (see Case 2)

\section{Wall Case V: Detroit and Ann Arbor Radical Publications}

New Force (vol. 1, nos.1, 3, January-August 1932).

New Force was the organ of the John Reed Club of Detroit

Ann Arbor publications which reflect the unrest of the Thirties:

Procession. Ann Arbor, 1931-32.

The Challenge Ann Arbor, 1939-40.

Leaflet. The Peace Primer. Ann Arbor: Young People's Socialist League,

Procession was a short-lived literary magazine edited by a group in which Harold Courlander, later famous for his novels, was prominent. The Challenge was the organ of the Michigan chapter of the American Student Union. 


\section{Wall Case VI: An Assortment of Radical Magazines \& Newsletters}

Arise. New York, 1937-40.

Arise succeeded Challenge (Chicago, 1933-35) as the organ of the Young People's Socialist League, the youth organization of the Socialist Party of the United States.

\section{Seed. 1941?.}

Seed was produced by the anarchists who formed the Brooklyn Youth Group.

Reveille. 1935-?.

Another extremely rare paper, Reveille presents the reactions of rebellious youths in the Civilian Conservation Corps, which reforested America duting the New Deal.

International of Youth. New York, 1934-35.

The montbly publication of the Young Communist League, the U.S.A. section of the Young Communist International.

\section{The Working Woman. New York, 1929-35.}

The Working Woman was a Communist journal. Myra Page, whose novel Moscow Yankee is in Case 4, was a regular contributor to this journal.

Power. New York, 1939-40?.

This extremely rare journal, was published by the Marxist Workers League, a very small left Trotskyist group headed by K. Milnov.

All Chicago. 1932-?

This very rare proletarian publication printed the work of Wobbly Ralph Chaplin.

Plain Talk, "Spokesman for the Forgotten Man". Washington, 1927-38. Plain Talk had a populist orientation: its editor and publisher, Morris A. Bealle (1891-1972), later became a pundit of the Radical Right. 
Special Collections Library

7th Floor, Harlan Hatcher Graduate Library University of Michigan

Ann Arbor, Michigan 48109-1205

(734) 764-9377

special.collections@umich.edu www.lib.umich.edu/spec-coll

\author{
Upcoming: \\ An Exhibit Celebrating the Work of Marge Piercy \\ August 30 - November 27, 2004
}

